\title{
気象・潮汐を考慮した水封式岩盤タンク 周辺地下水位の変動評価
}

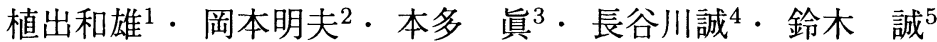 \\ ${ }^{1}$ 日本地下石油備蕃 (株) （テ 105-0012 港区芝大門 2-10-12 秀和第 3芝パークビル) \\ 2 工博 日本地下石油備蓄 (株) (テ 105-0012 港区芝大門 2-10-12 秀和第 3 芝パークビル) \\ 3 正会員 工博 清水建設 (株) 和泉研究室 (テ 100-0011 千代田区内幸町 2-2-2 富国生命ビル) \\ 4 正会員 工博 清水建設（株）土木事業本部（テ 105-8007 港区芝浦 1-2-3 シーバンス $\mathrm{S}$ 館） \\ 5 正会員 工博 清水建設 (株) 和泉研究室 (广 100-0011 千代田区内幸町 2-2-2 富国生命ビル)
}

\begin{abstract}
水封式岩盤タンク周辺の地下水位は降水による影響はもとより, 気圧変動, 地球潮汐などによる自然影響要 因や，水封制御のための給水流量変動などにより大きく变動する.このような变動の中から, 地震やその他の 要因に伴う水理構造変化による影響を見いだすことが, 水封機能管理において極めて重要となる.したがって, 本研究では時系列解析手法を用いて, 気圧や潮汐, 降水による影響を分離するとともに維持管理モデルとして の可能性を検証した。 その結果, 気圧・潮汐・降水等の自然因子による影響を取り除き, 水理構造の变化等に伴 う水位変動の検出が可能であることがわかり，水封機能管理モデルとしての適用性を示した.
\end{abstract}

Key Words : ground water level, water seal, rock cavern, time series analysis, AR model

\section{1.はじめに}

水封式岩盤タンクにおいて水封機能の確保には，常 に地下水位変動を観測し, 地下水位を維持するように 制御を行う必要がある。このため岩盤タンク周辺に設 置した多くの観測孔において, 孔内地下水位の経時的 な変動を常時自動観測している。

孔内地下水位の変動は降水変動による影響はもとよ り, 気圧変動, 地球潮汐などの自然影響因子により大 きく変動する．また人工水封方式では水封機能確保の ため水封水位を一定に保つべく給水による制御を実施 しており, 給水流量変動や水封水位変動も孔内水位の 変動に影響を及ほしている。このため水封機能の管理 としては, 孔内地下水位の観測のみならず, 水封水位 や給水流量, 夕ンク内湧水流量, さらには気圧, 降水 や潮汐変動など, 数多くのデー夕変動を経時的に観測 している．このような複雑に影響し合うデー夕変動を モデル化し, 地下水位変動に含まれる地震やその他の 影響によって生じた水理構造の変化を見いだすことが, 水封機能の管理において極めて重要な課題である.

一般に設計段階における地下水挙動の把握には物理 モデルに基づく浸透流解析が用いられるが, 多数の観 測データを取り込んでリアルタイムに解析を実施する 必要のある維持管理の段階では, 統計的な時系列解析 手法を用いるのが現実的である. 地下水位変動と外因 との関倸を統計モデルにより扱った研究には, 単純な 一次回帰分析と調和解析により分析したもの1)などがあ
るが, 本研究で対象とする水封式岩盤タンク周辺地下 水位は, 自然状態の地下水位とは異なり，人工水封制 御により複雑なメカニズムを有して変動している。こ のメカニズムを気象や潮汐, 水封制御関連デー夕など を考慮してモデル化することで, 降水や潮汐などの影 響を定量的に評価し, 地下水挙動の異常を検出可能な 管理モデルを構築することが本研究の目的である.

そこで菊間国家石油備蓄基地における各種デー夕を 用いて, 時系列解析手法による孔内地下水位変動のモ デル化を行い, 気圧や潮汐, 降水による影響の定量的 な評価に関する検討を実施した。

具体的にはまず，孔内地下水位の時系列モデルを状 態空間モデルを用いて表現して, 気圧, 潮汐, 降水の影 響を分離する手法を試みる。この手法は, 地震予知研 究の一環として地震に先行する地下水位変化を検出す ることを目的として, 観測データから気圧, 潮汐, 降 水の影響を分離するためのモデルとして提案されたも のである2),3),4)

次に水封制御に伴う複雑な影響を考慮するために, 多 変量自己回帰モデルによるモデル化を試みる. 多変量 自己回帰モデルは，定量的な要因分析が可能であると 共に, システム全体の解析を基にシステム制御が可能 である. 多変量自己回帰モデルを用いたシステム制御 の方法を先駆的に示したのが，セメントプラントのキ ルンプロセスの制御に用いた赤池ほか5)であり，その後 多くの制御工学の分野でシステム制御に用いられてい $ろ^{6)}$. 著者らは既に, 降水変動の影響を含む地下水挙動 
データに対して，多変量自己回帰モデルを用いた管理 モデルの提案を行っており7)，ここではこのモデルを用 いて降水影響成分を定量的に評価し，水封機能維持管 理モデルとしての可能性について検討する.

\section{2. 地下水関連データ変動の因果関係}

図-1 は, 人工水封式岩盤タンクにおける地下水関連 デー夕相互の因果関係を概念的に示した図である。図 中の矢印は各デー夕変動が影響を与えることを示すも のである.

水封機能確保においては, タンクに向かう動水勾配 を確保することが重要であり，そのために周辺地下水位 を設計限界水位以上に維持することが求められる，孔 内地下水位変動に影響を及ほす自然因子には, 降水, 気 圧およ地球潮汐があげられる。このうち気圧や潮汐は， 直接独立に各観測孔地下水位の変動に影響を与える。こ れに対して降水変動の影響は, 降水浸透が直接孔内地 下水位に影響を与えるだけでなく，極めて複雑に孔内 地下水位に影響を及ほす。人工水封制御時には，図に 示すように水封トンネルの水位（水封水位）を一定に 保つように, 竪坑への給水流量を増減させて制御して いる.この水封水位は降水浸透の影響を受けて変動し ようとするため, 結果として給水流量の変動は降水量 変動の影響を受ける。

また通常は一定に保たれている水封水位も, 給水を 行っていない自然水封の状態では変動することになる. 孔内地下水位変動は, このような水封水位の変動の影 響も受ける.タンク内への湧水流量についても同様に, 降水浸透が直接影響を及ほすだけでなく, 給水流量変 動や水封水位変動を介して影響を及ほしている.

図-2 は, 水封水位変動と給水流量変動および日降水 量との関係を例示したものである.この例では, 水封 水位は下限值を $0.45 \mathrm{~m}$ 程度で制御しているが, 給水流 量を 0 としたときには水封水位が上昇することがある （1997 年 8 月や 1999 年 6 月〜 12 月など）。すなわち給 水流量 0 の期間は自然水封状態で水封水位も自由に変 動する，ただし計測設備の特性上水封水位は $1.12 \mathrm{~m}$ で 頭打ちになっている. 日降水量との関係を見ると, 給 水流量が減少あるいは 0 となる期間は降水量が多い期 間と一致していることがわかる。

また運用開始の 1994 年から徐々に給水流量は減少し ており，1994年当初の 4 分の 1 程度となっていること もわかる。これは運用開始から目詰まり等と推定される 要因により徐々に水みちが変化していると考えられる.

孔内地下水位は, 一般に降水の影響を受けて降水が 多いときに水位が上がり, 少ないときに水位が下がる傾 向を示す.この変動傾向は給水流量の変動傾向に対して

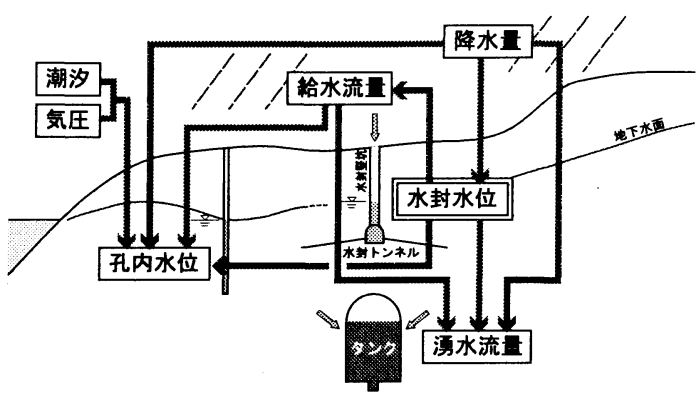

図-1 地下水関連データの因果関係概念図

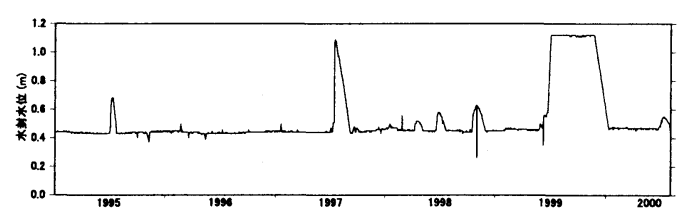

a) 水封水位

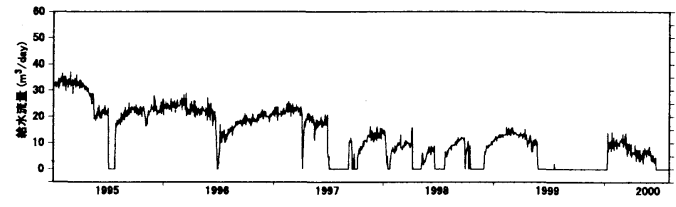

b) 給水流量

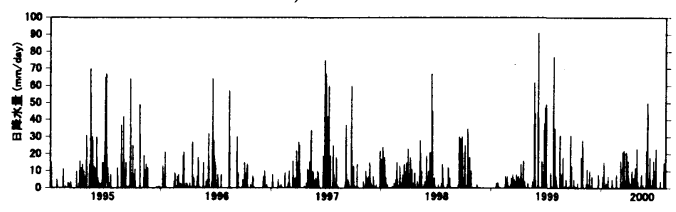

c) 日降水量

図-2 水封水位と給水流量および日降水量の関係例（払出竪坑）

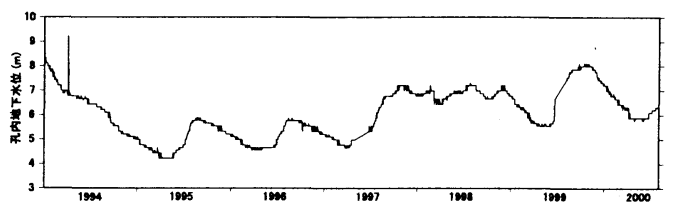

W-11 孔地下水位

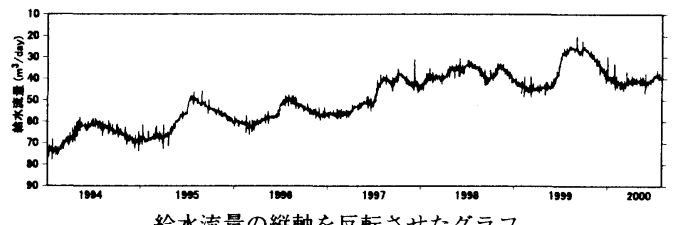

給水流量の絴軸を反転させたグラフ

図-3 給水流量との強い負の相関性

負の相関性を示すことになる. 図-3 は例として W-11 孔地下水位と水封㹂坑給水流量のグラフの縦軸を逆転 したものを比較して示したものである．2つのグラフ は極めて変動が似通っており, 孔内水位が上昇すると 
給水流量が減り，孔内水位が下がると給水流量が増え る傾向となっている。これは降水変動の影響により変 動しようとする水封水位の制御を通して給水流量変動 に現れたものであり,この関係は, 後に示す降水変動 と孔内水位変動の関係を表すモデル構築において極め て重要な意味を持つ。

上述のように孔内水位変動の統計的なモデル化にお いては, 気圧および潮汐は独立に影響を受けるものと して考えることができるが, 降水変動は浸透した降水 が大きな時間遅れを伴って受ける直接の影響だけでな く, 人工水封の制御に伴って, 給水量变動や水封水位 変動を介した間接的な関係を考慮する必要がある.

本論文では, 次の 2 種類のモデルによる孔内地下水 位変動の評価に関する検討を実施した。

\section{・ 状態空間モデルによる影響分離手法}

予め各影響成分の線形モデルを定義して，これら の和として地下水位が表されるものとして, 状態 空間モデルによるモデル化・各成分の推定を行う 方法である.

- 多変量自己回帰モデルによる降水影響評価手法 給水流量や水封水位など水封制御デー夕による相 互の影響を考慮するために，これらのデー夕を変 数とした多変量自己回帰モデルにより地下水位変 動をモデル化し，各変量の寄与率や降水量や水封 水位を制御したときのシミュレーションなどを通 して，降水影響を評価するものである.

2 つの手法は基本的に，変量相互の相関性を考慮する か否かにおいて考え方が異なる.

\section{3. 状態空間モデルによる潮汐・気圧・降水 影響成分分離検討}

\section{（1）状態空間モデルによる影響分離手法}

本手法は文献2),4)に基づくもので, 地下水位変動を気 圧, 潮汐, 降水の 3 つの影響成分とそれ以外の変動の 4 つに分離できるものと仮定して，それぞれの影響成 分をモデル化する。

\section{a) 孔内地下水位の時系列モデル}

孔内地下水位の観測デー夕を $y_{n}(n=1, \ldots, N)$ とす るとき, 気圧の影響 $P_{n}$, 地球潮汐の影響 $E_{n}$, 降水の 影響 $R_{n}$ を用いた次式のモデルで表されると仮定する.

$$
y_{n}=t_{n}+P_{n}+E_{n}+R_{n}+\varepsilon_{n}
$$

ここで， $\varepsilon_{n}$ は観測ノイズ等を表すもので，上記モデル で表現しきれなかった成分が含まれる，これを平均 0 ， 分散 $\sigma^{2}$ の正規白色ノイズと仮定する。気圧，潮汐およ
び降水の影響は以下に示すモデルで表現する。

$$
\begin{aligned}
& \text { 気圧の影響 }: P_{n}=\sum_{i=0}^{l} a_{i} p_{n-i} \\
& \text { 潮汐の影響 }: E_{n}=\sum_{i=0}^{m} b_{i} e_{n-i} \\
& \text { 降水の影響 }: R_{n}=\sum_{i=1}^{k} c_{i} R_{n-i}+\sum_{i=1}^{k} d_{i} r_{n-i}
\end{aligned}
$$

ここで, $p_{n}$ および $e_{n}$ はそれぞれ気圧，潮高デー夕で, ここではこれらの影響を時間遅れの影響を考慮したイ ンパルス応答型のモデルで表している。また降水の影 響は, 降水量データ $r_{n}$ を入力とする自己回帰型の線形 モデルで表し, 少数の変数で長時間の積算効果の影響 が考慮できる。

$t_{n}$ は気圧, 潮汐, 降水の影響を除去した後に残る地 下水位の変動成分（トレンド成分）であり，いわゆる 「補正後の地下水位」である. トレンドは急激な変化を しないという条件で，以下のようなランダムウォーク モデルに従って徐々に変化するものと仮定する.

トレンド（補正後の地下水位）: $t_{n}$

$$
t_{n}=t_{n-1}+v_{n}, \quad v_{n} \sim N\left(0, \tau^{2}\right)
$$

\section{b) 状態空間モデルによる表現}

地下水位 $y_{n}$, 気压 $p_{n}$, 降水量 $r_{n}$, 潮高 $e_{n}$ の観測値 が時系列 $(n=1, \ldots, N)$ データとして与えられるとき， 先のモデル式 (1) (5) を次の状態空間モデルで表して, トレンド $t_{n}$ を求める.

$$
\begin{array}{ll}
x_{n}=F x_{n-1}+M r_{n-1}+G v_{n} & (\text { システムモデル) } \\
y_{n}=H_{n} x_{n}+w_{n} & \text { (観測モデル) }
\end{array}
$$

$x_{n}$ は状態べクトルで, 次式で表される.

$$
\begin{aligned}
x_{n}=\left(t_{n}, a_{0}, \ldots, a_{l}, b_{0}, \ldots, b_{m},\right. & \\
& \left.R_{n}, \hat{R}_{n+1 \mid n-1}, \ldots, \hat{R}_{n+k-1 \mid n-1}\right)^{t}
\end{aligned}
$$

なお, $\hat{R}_{n+i \mid n-1}$ は $R_{n+i}$ の $n-1$ 時点までの観測值か ら決まる部分を示し，次式で表される。

$$
\hat{R}_{n+i \mid n-1}=\sum_{j=i+1}^{k} c_{j} R_{n+i-j}+\sum_{j=i+1}^{k} d_{j} r_{n+i-j}
$$

また $v_{n} \sim N\left(0, \tau^{2}\right), w_{n} \sim N\left(0, \sigma^{2}\right)$ であり，さらに，

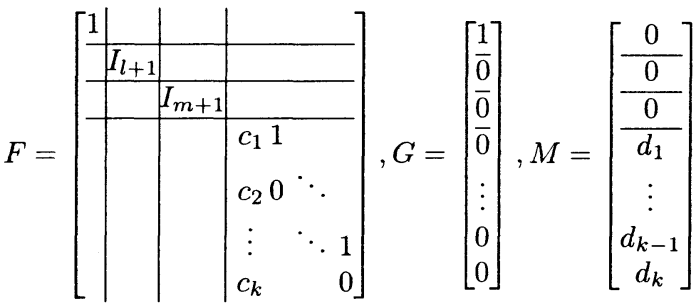


表-1 状態空間モデルに置いて推定すべきパラメータ

\begin{tabular}{clr}
\hline & $t_{1}, \ldots, t_{N}$ & $N$ 個 \\
& $a_{0}, \ldots, a_{l}$ & $l+1$ 個 \\
& $b_{0}, \ldots, b_{m}$ & $m+1$ 個 \\
& $R_{1}, \ldots, R_{N}$ & $N$ 個 \\
\hline \multirow{3}{*}{ ハイパーパラメータ } & $c_{1}, \ldots, c_{k}$ & $k$ 個 \\
& $d_{1}, \ldots, d_{k}$ & $k$ 個 \\
& $\tau^{2}, \sigma^{2}$ & 2 個 \\
\hline \hline 計 & $2 \times(N+k)+l+m+4$ 個
\end{tabular}

$H_{n}=\left(1, p_{n}, \ldots, p_{n-l}, e_{n}, \ldots, e_{n-m}, 1,0, \ldots, 0\right)$

ただし， $I_{l+1}$ は $(l+1) \times(l+1)$ の単位行列である. 以上がこの時系列モデルの状態空間表現である。こ のとき推定しなくてはならない未知量は表-1 の通り である，上記の状態空間モデルにおいて，パラメー夕 $\sigma^{2}, \tau^{2}, c_{1}, \ldots, c_{k}, d_{1}, \ldots, d_{k}$ を既知と仮定すれば，カル マンフィルタと平滑化アルゴリズムを用いることで, 観 測値の時系列 $y_{n}$ に基づいて状態 $x_{n}$ の推定を行うこと ができる. 状態ベクトル $x_{n}$ が推定されれば，トレンド $t_{n}$ のほかに，降水の影響 $R_{n}$, 気圧の影響係数 $a_{i}$ およ び潮汐の影響係数 $b_{i}$ の推定值が得られることになる.

またパラメータ $\sigma^{2}, \tau^{2}, c_{1}, \ldots, c_{k}, d_{1}, \ldots, d_{k}$ は，事前 分布のパラメータということでハイパーパラメータと 呼ばれ，この推定にはカルマンフィルタのアルゴリズ ムの中で求められる尤度を最大とする最尤法を用いる。 さらに各モデルの次数 $l, m, k$ は，いくつかのケースを 設定して計算を行い，情報量規準 $\left.\mathrm{AIC}^{8}\right)$ が最小となる 次数を選択する.

\section{(2) 検討内容}

\section{a) 検討対象}

図-4に示した菊間基地における 14 孔の孔内地下水 位デー夕を対象として検討を実施し，ここでは図 -5 中 の 3 孔（W-4,W-9,W-11 孔）の孔内地下水位の検討結 果を例として示す. 対象期間は 1995 年 1 月 1 日 2000 年 7 月 31 日の 5 年半で 1 日毎（毎日午前 10 時に計測) のデータである. 図-6 は対象期間の気圧, 潮高, 日降 水量を示したものである（敷地内に計測器を設けて常 時観測)。なお潮高データについては 1 日の中でも周期 変動するため，1 時間毎のデータからモデル化精度が 最も良かった午前 9 時のデー夕を用いた。

\section{b) 解析手順}

気圧，潮汐，降水の影響モデルの様々な次数の組合 せについて最適次数を求めるのは, 計算時間が膨大と なるため, 実際の解析では以下の手順で実施する.

気圧および潮汐の影響モデルの次数決定 まず最初に， 気圧と潮汐の影響のみを考慮し，降水影響を除いた次

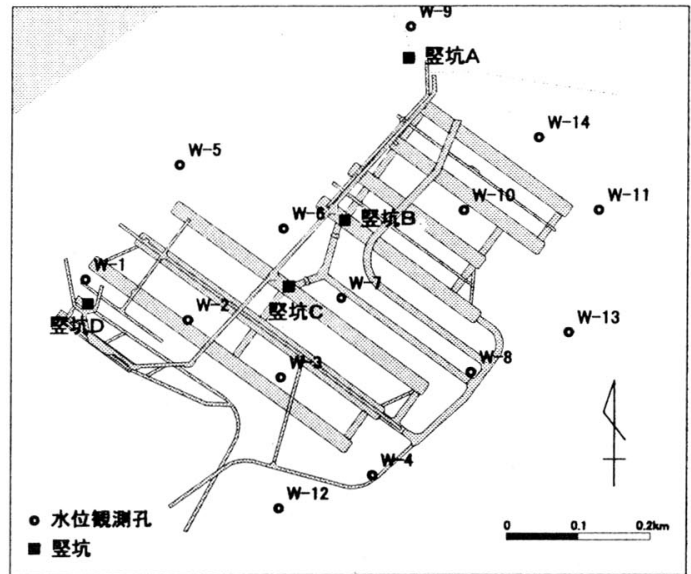

図-4 孔内水位観測孔位置図（菊間基地）

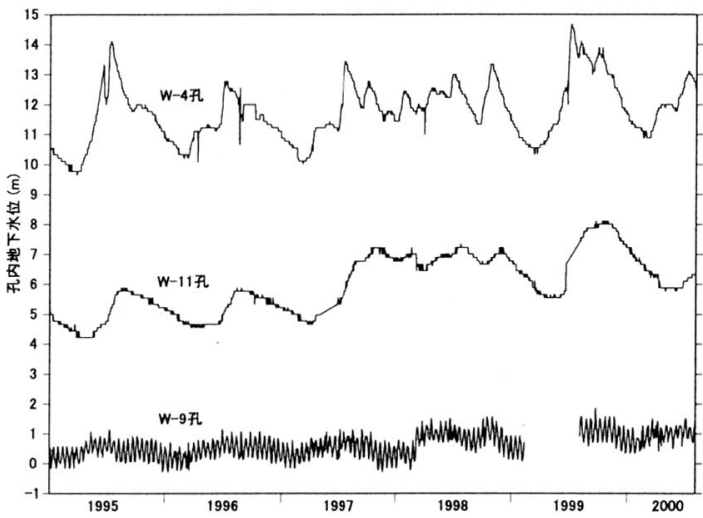

図-5 孔内地下水位

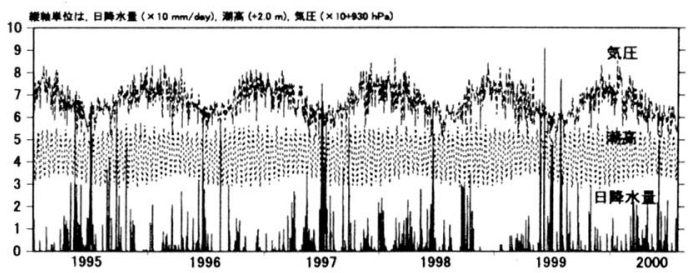

図-6 気圧・潮高・降水データ

式のモデルについて最適な次数を決定する.

$$
y_{n}=t_{n}+\sum_{i=0}^{l} a_{i} p_{n-i}+\sum_{i=0}^{m} b_{i} e_{n-i}+\varepsilon_{n}
$$

このモデルの状態空間表現は, 式 (10) から降水の影響 を除いて，以下のように表す。

$$
\begin{gathered}
F=\left[\begin{array}{l|l|l}
1 & & \\
\hline & I_{l+1} & \\
\hline & & I_{m+1}
\end{array}\right], \quad G=\left[\begin{array}{c}
1 \\
\hline 0 \\
\hline 0
\end{array}\right] \\
H_{n}=\left(1, p_{n}, \ldots, p_{n-l}, e_{n}, \ldots, e_{n-m}\right)
\end{gathered}
$$


表-2 各観測孔の気圧・潮汐・降水の影響次数と影響評価

\begin{tabular}{|c|c|c|c|c|c|c|c|}
\hline & \multicolumn{3}{|c|}{ モデル次数 } & \multirow{2}{*}{$\mid \begin{array}{l}\mid \text { 気圧 } \\
\text { 影䈉 }\end{array}$} & \multirow{2}{*}{$\mid$} & \multirow{2}{*}{$\begin{array}{l}\text { 降水 } \\
\text { 影響 }\end{array}$} & \multirow[b]{2}{*}{ 結果評㑣 } \\
\hline & \begin{tabular}{|c} 
気压 \\
$l$
\end{tabular} & $\begin{array}{c}\text { 潮汐 } \\
m \\
m\end{array}$ & \begin{tabular}{|c|} 
降水 \\
$k$
\end{tabular} & & & & \\
\hline W-4 孔 & 1 & 0 & 1 & \begin{tabular}{|l|l} 
無 \\
\end{tabular} & $\begin{array}{ll}\text { 無 } \\
\end{array}$ & (2) & $\times($ 降水モデルに難あり) \\
\hline W-9 孔 & 1 & 5 & 1 & 0 & () & |ほほ無 & ○ (潮汐影響分離 可) \\
\hline W-11 孔 & 1 & 0 & 15 & 無 & 無 & () & $\triangle$ (降水モデルに難あり) \\
\hline
\end{tabular}

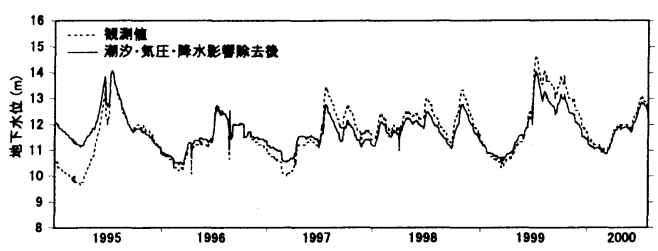

a) 実測孔内水位と補正後地下水位

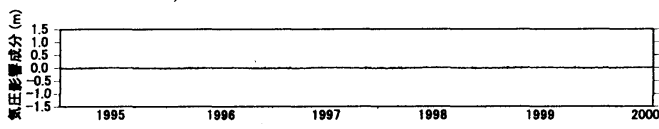

b) 気圧影響成分

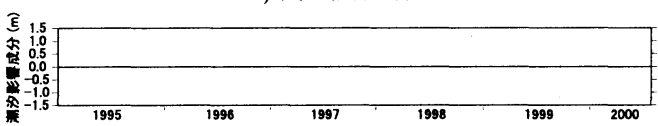

c) 潮汐影響成分

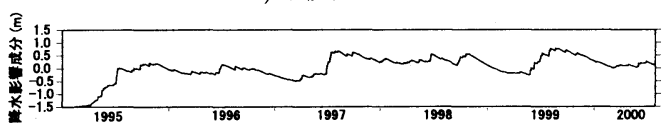

d) 降水影響成分

図-7 補正後地下水位変動と各影響成分（孔内水位W-4）

降水の影響モデルの次数決定 同じ期間のデー夕を用 いて, 先に決定した気圧および潮汐影響モデルの次数 を固定して，降水影響モデルの最適な次数を決定する. 全対象期間のトレンド（補正後地下水位）の推定 上 記で決定した気圧, 潮汐, 降水の影響モデルの次数 $l$, $m, k$ を固定して, カルマンフィルタと平滑化アルゴリ ズムにより全対象期間のトレンド（補正後の地下水位） を推定する。

\section{(3) 検討結果}

最終的に対象期間全体に対して適用した結果につい て述べる。表-2 は 3 つの観測孔デー夕について, 決定 された各影響モデルの次数 $l, m, k$ と影響分離結果の評 価を示したものである.W-9 孔は海に近いことから潮 汐の影響を受けて, 潮汐影響モデルの次数が他孔より 高いことがわかる.またW-11 孔は降水影響モデルの次 数が高く，長期的な降水影響が認められる．また推定 結果として補正後地下水位, 気圧影響成分, 潮汐影響 成分，降水影響成分のグラフを図-7〜図-9 に示した。 なお各図の a) は実測孔内水位（細線）と影響除去後の

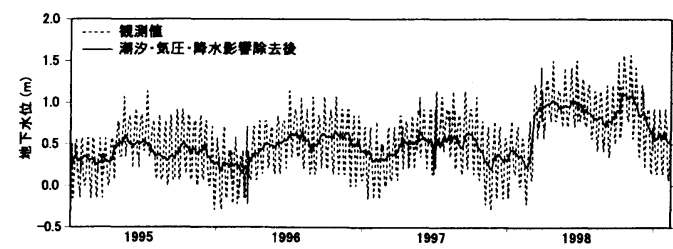

a) 実測孔内水位と補正後地下水位

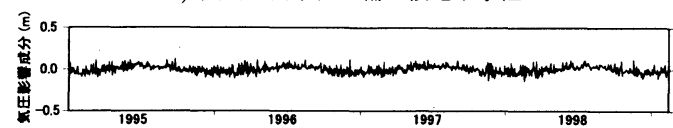

b) 気圧影響成分

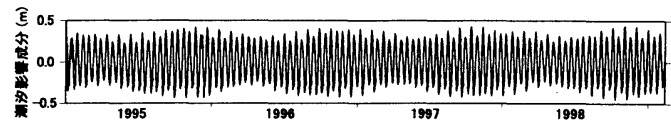

c) 潮汐影響成分

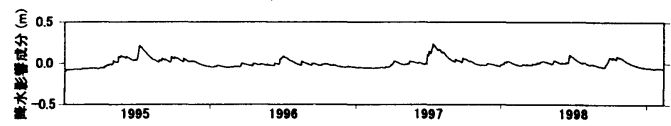

d) 降水影響成分

図-8 補正後地下水位変動と各影響成分（孔内水位W-9）

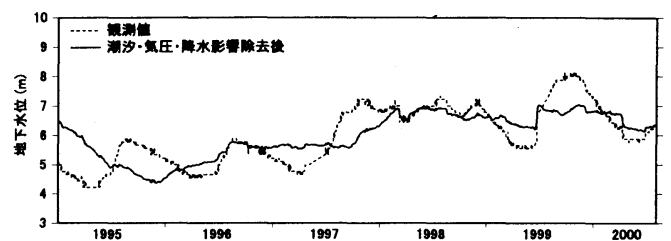

a) 実測孔内水位と補正後地下水位

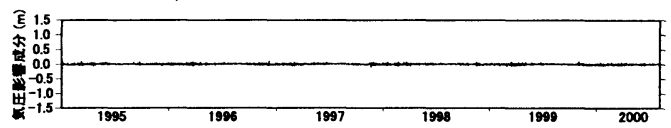

b) 気圧影響成分

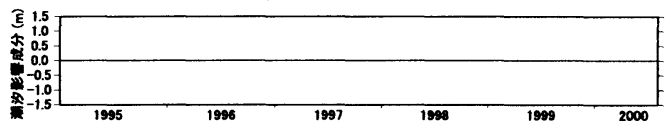

c) 潮汐影響成分

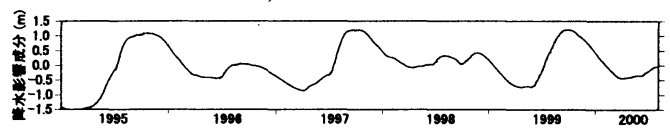

d) 降水影響成分

図-9 補正後地下水位変動と各影響成分（孔内水位W-11）

補正水位（太線）を示し，b)，c)，d）はそれぞれ気圧， 潮汐，降水の影響成分を示したものである.

まず図-7のW-4 孔を見ると，気圧および潮汐の影響 は共に検出されておらず，降水についても最大 $1.5 \mathrm{~m}$ 程 度の僅かな影響を検出しているが, 補正後地下水位は観 測値とほとんど変わらない結果となった. 同様に図-9 のW-11 孔を見ると，やはり気圧および潮汐の影響は検 出されていない，降水による影響成分は，変動傾向を ある程度捉えることができているものの, 補正後地下 
水位には, 除去しきれなかった降水変動成分が残って いる.

このように降水による影響と考えられる変動成分は, 十分な精度で分離することができなかった。これは, 起 因となる変動は降水変動によるものであっても, 水封 制御による供給流量の変動や水封水位の変動による影 響が複雑に絡んでおり，ここで定義した単純な自己回 帰型降水影響モデル（式 (4)) では表しきれないものと 考えられる.

本手法により有効に影響分離ができたのは，潮汐の 影響を強く受けて変動しているW-9 孔（図-8）であっ た。潮汐による周期的な変動を精度良く分離でき, 潮 汐変動に隠れていた数 $10 \mathrm{~cm}$ 程度のわずかな変動が明 確になった. 特に 1998 年 3 月頃には約 $50 \mathrm{~cm}$ の水位上 昇が明確に認められる。なお気圧の影響は若干検出さ れているが, 絶対量としては他の観測孔と比較して特 に有意ではない。

以上のことを踏まえて，表-2 には定性的な結果の評 価を示した。

\section{4. 多変量自己回帰モデルによる降水影響評 価検討}

状態空間モデルによる影響成分の分離では，潮汐変 動は精度良く分離できたが, 降水の影響は十分な精度 で分離できなかった，そこで，ここでは既に著者らが 提案している制御系多変量自己回睓モデル5)に基づく 地下水位変動の管理モデル7)を用いて, 給水流量や水封 水位など水封制御データによる相互の影響を考慮して, 降水影響を評価する手法の検討を実施した。

\section{（1）多変量自己回帰モデルによる降水影警評価手法 \\ a）孔内水位変動のモデル化}

各観測孔毎の孔内水位変動 $y_{n}$ は次式の多変量自己回 㷌モデル (Multivariate AutoRegressive model)（以下 MAR モデルと呼ぶ）で表されるとする.

$$
\begin{gathered}
\left\{\begin{array}{c}
y_{n} \\
\left(\mathbf{Q}_{n}\right) \\
\left(\mathbf{F}_{n}\right) \\
\left(R_{n}\right) \\
\left(P_{n}\right) \\
\left(\mathbf{H}_{n}\right)
\end{array}\right\}=\mathbf{A}(1)\left\{\begin{array}{c}
y_{n-1} \\
\mathbf{Q}_{n-1} \\
\mathbf{F}_{n-1} \\
R_{n-1} \\
P_{n-1} \\
\mathbf{H}_{n-1}
\end{array}\right\}+\mathbf{A}(2)\left\{\begin{array}{c}
y_{n-2} \\
\mathbf{Q}_{n-2} \\
\mathbf{F}_{n-2} \\
R_{n-2} \\
P_{n-2} \\
\mathbf{H}_{n-2}
\end{array}\right\}+\ldots \\
+\mathbf{A}(M)\left\{\begin{array}{c}
y_{n-M} \\
\mathbf{Q}_{n-M} \\
\mathbf{F}_{n-M} \\
R_{n-M} \\
P_{n-M} \\
\mathbf{H}_{n-M}
\end{array}\right\}+\mathbf{e}(t)
\end{gathered}
$$

ただし， $y_{n}$ : 孔内地下水位, $\mathbf{Q}_{n}$ : 各給水流量のベクト ル, $\mathbf{F}_{n}$ : 各湧水流量のベクトル, $R_{n}$ : 日降水量, $P_{n}$ : 気圧, $\mathbf{H}_{n}$ : 各水封水位のベクトルで, 何れも時刻 $n$ ス
テップ時である.また $M$ はモデルの次数, $\mathbf{A}(m)$ は回 帰式の重み係数ベクトルで, 次式のユールウォーカー 方程式を解くことで求められる.

$$
\begin{array}{r}
{\left[\begin{array}{cccc}
\hat{\mathbf{C}}^{T}(0) & \hat{\mathbf{C}}^{T}(-1) & \ldots & \hat{\mathbf{C}}^{T}(1-M) \\
\hat{\mathbf{C}}^{T}(1) & \hat{\mathbf{C}}^{T}(0) & \ldots & \hat{\mathbf{C}}^{T}(2-M) \\
\vdots & \vdots & \ddots & \vdots \\
\hat{\mathbf{C}}^{T}(M-1) & \hat{\mathbf{C}}^{T}(M-2) & \ldots & \hat{\mathbf{C}}^{T}(0)
\end{array}\right]\left[\begin{array}{c}
\mathbf{A}^{T}(1) \\
\mathbf{A}^{T}(2) \\
\vdots \\
\mathbf{A}^{T}(M)
\end{array}\right]} \\
\quad=\left[\begin{array}{c}
\hat{\mathbf{C}}^{T}(1) \\
\hat{\mathbf{C}}^{T}(2) \\
\vdots \\
\hat{\mathbf{C}}^{T}(M)
\end{array}\right] \quad(16)
\end{array}
$$

ここで $\hat{\mathbf{C}}(m)$ は, 各変数間の自己一相互相関関数で ある。

上記モデルにおいて他から影響を受けずに独立して 変動する項目は, 日降水量 $R_{n}$, 気圧 $P_{n}$ および各水封 水位 $\mathbf{H}_{\mathbf{n}}$ である. 一方, 給水流量 $\mathbf{Q}_{\mathbf{n}}$ や湧水流量 $\mathbf{F}_{\mathbf{n}}$ は 降水や水封水位変動の影響を受ける. 制御系の MAR モ デルとして考える場合, 通常, 前者の変量を操作変数 (人為的に制御され独立に与えられる変数)，後者を被 制御変数（予測管理すべき变数）とするが，ここでは孔 内地下水位 $y_{n}$ のモデル化が目的であり, 給水流量 $\mathbf{Q}_{\mathbf{n}}$ や湧水流量 $\mathbf{F}_{\mathbf{n}}$ をも推定するモデルとした場合, 孔内地 下水位の推定に最適なモデル構築とならない可能性が ある.また給水流量は孔内地下水位に影響を及ぼすが, 逆に孔内地下水位が給水流量や湧水流量に直接的に影 響を与えることはない。このことことからも給水流量 や湧水流量は別途に予測モデルを構築して降水量の影 響を評価することとして，ここでは孔内地下水位以外 の変量は全て常に独立に与えられる操作変数としてモ デル化する. したがって先の式 (15) の左辺には, 孔内 地下水位 $y_{n}$ 以外の項は ( ) を付けて表し, 予測する必 要のない操作変数であることを示している.

\section{b) 給水流量変動および湧水流量変動のモデル化}

式 (15) において独立な操作変数としてモデル化した 給水流量 $\mathbf{Q}_{\mathbf{n}}$ と湧水流量 $\mathbf{F}_{\mathbf{n}}$ の変動は, 降水と水封水位 の影響を受けるため予め別のモデルで降水影響を評価 する必要がある。

まず給水流量 $\mathbf{Q}_{\mathbf{n}}$ の変動は, 降水量 $R_{n}$ と各水封水位 $\mathbf{H}_{\mathrm{n}}$ の影響を考慮して次式のモデルで表されるとする.

$$
\begin{aligned}
\left\{\begin{array}{c}
\mathbf{Q}_{n} \\
\left(R_{n}\right) \\
\left(\mathbf{H}_{n}\right)
\end{array}\right\}=\mathbf{A}(1) & \left\{\begin{array}{c}
\mathbf{Q}_{n-1} \\
R_{n-1} \\
\mathbf{H}_{n-1}
\end{array}\right\}+\mathbf{A}(2)\left\{\begin{array}{c}
\mathbf{Q}_{n-2} \\
R_{n-2} \\
\mathbf{H}_{n-2}
\end{array}\right\}+\ldots \\
& +\mathbf{A}(M)\left\{\begin{array}{c}
\mathbf{Q}_{n-M} \\
R_{n-M} \\
\mathbf{H}_{n-M}
\end{array}\right\}+\mathbf{e}(t) \quad(17)
\end{aligned}
$$

これは日降水量 $R_{n}$ および各水封水位 $\mathbf{H}_{\mathbf{n}}$ を操作変数 とした制御系 MAR モデルである。 
一方, 湧水流量 $\mathbf{F}_{n}$ の変動は, 降水量 $R_{n}$ と各水封水 位 $\mathbf{H}_{n}$ に加えて上記モデルで予測される給水流量 $\mathrm{Q}_{n}$ の影響を受けるものとして，次式の制御系 MAR モデ ルで表されるとする。

$$
\begin{gathered}
\left\{\begin{array}{c}
\mathbf{F}_{n} \\
\left(\mathbf{Q}_{n}\right) \\
\left(R_{n}\right) \\
\left(\mathbf{H}_{n}\right)
\end{array}\right\}=\mathbf{A}(1)\left\{\begin{array}{c}
\mathbf{F}_{n-1} \\
\mathbf{Q}_{n-1} \\
R_{n-1} \\
\mathbf{H}_{n-1}
\end{array}\right\}+\mathbf{A}(2)\left\{\begin{array}{c}
\mathbf{F}_{n-2} \\
\mathbf{Q}_{n-2} \\
R_{n-2} \\
\mathbf{H}_{n-2}
\end{array}\right\}+\ldots \\
+\mathbf{A}(M)\left\{\begin{array}{c}
\mathbf{F}_{n-M} \\
\mathbf{Q}_{n-M} \\
R_{n-M} \\
\mathbf{H}_{n-M}
\end{array}\right\}+\mathbf{e}(t) \quad(18)
\end{gathered}
$$

c) 降水影響評価シミュレーション

上述のモデルで孔内地下水位変動への降水影響評価 を行う方法は以下の通りである.

（a）まず給水流量変動モデル（式 (17)）で, 降水量 $R_{n}$ を 0 ，各水封水位 $\mathbf{H}_{n}$ に管理水位值 $\mathbf{H c}_{n}$ を与えて 各給水流量変動のシミュレーション值 $\tilde{\mathbf{Q}}_{n}$ を得る.

（b）次に涌水流量変動モデル（式 (18)）で, 降水量 $R_{n}$ を 0 , 各水封水位に管理水位值 (一定値) $\mathbf{H c}_{n}$, さ らに各給水流量に先に得られたシミュレーション 値 $\tilde{\mathrm{Q}}_{n}$ を与えて, 各湧水流量変動のシミュレーショ ン值 $\tilde{\mathbf{F}}_{n}$ を得る。

(c) 最後に各孔内地下水位変動モデル（式 (15)) で, 降 水量 $R_{n}$ を 0 , 各水封水位に管理水位值（一定値） $\mathrm{Hc}_{n}$, 各給水量にシミュレーション值 $\tilde{\mathbf{Q}}_{n}$, 各湧水 流量に同じくシミュレーション值 $\tilde{\mathbf{F}}_{n}$ をちえて, 孔 内地下水位のシミュレーション值 $\tilde{y}_{n}$ を求める。 こ れをモデルの再現値と比較することで，降水影響 成分の評価を行う。

以降は, 先に示した図-5 の孔内地下水位, 図-6 の 日降水量に加えて, 図-10 に示す水封制御関連デー夕 （水封水位, 給水流量, 湧水流量) を用いて, 上記モデ ルによる検討を実施した結果について述べる.

\section{（2）給水流量変動と湧水流量変動のモデル化と降水影 響評価}

図-10は，対象とする菊間基地における水封制御関 連デー夕を示している. 菊間基地では水封機能確保のた め先の図-4に示した $\mathrm{A} \sim \mathrm{D}$ の 4 力所の竪坑水位（水封 水位）を一定に保つように給水を実施しており，図-10 a) はその竪坑水位（水封水位）を示し, 図-10 b) はそ れぞれの給水流量を示す.またタンク内の全湧水流量 を示したものが図-10 c) である.

給水流量および湧水流量データの変動を見ると, 運 用開始の 1994 年以降徐々に減少する傾向がある. 目詰 まり等の現象によるものと推定されており, 減少の割

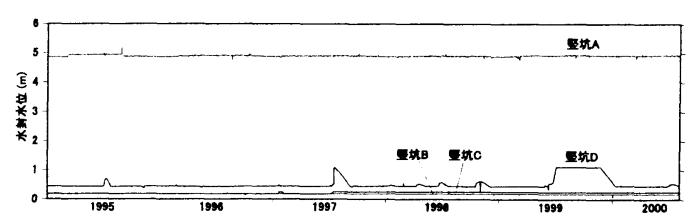

a) 水封水位 観測値

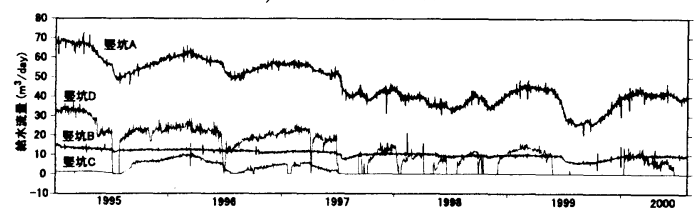

b) 給水流量 観測値

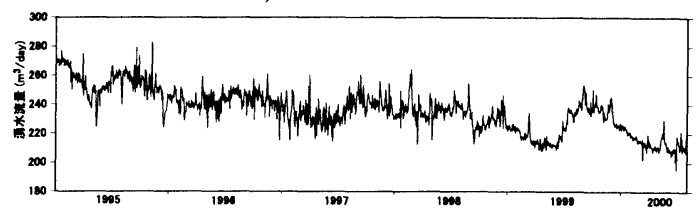

c) 全体湧水流量·観測值

図-10 水封制御関連デー夕

合は徐々に小さくなっている. 先述の MAR モデルは 定常状態を仮定したものであり，このような非定常な 挙動は予め取り除かなければモデルの再現精度が悪い. そこで漸減現象を指数関数モデルの回帰によって取り 除いてデー夕を補正する. 漸減の近似モデルとして次 式の負の指数関数を提案する.

$$
Q(t)=a \cdot \exp \left(-\frac{t-b}{a}\right)+c
$$

ただし $t$ は時刻, $a, b, c$ は回帰係数である. 対象期間を 決めてデー夕にあてはめて最小二乗法により回帰係数 を求める.

図-11 および図-12 はそれぞれ，給水流量（例とし て竪坑 A）と全体湧水流量を上記の式で回帰した結果 を各図-a)に示し，漸減トレンドを取り除いた補正後の デー夕を各図-b) に示した．これらを見ると極めて精度 良く漸減減少を近似でき, 補正後デー夕は定常性が満 たされているものと考えられる.

補正された給水流量および湧水流量デー夕に対して, ここでは式 (17) および式 (18)のモデルを構築して, そ れぞれの降水による影響を評価する。まず給水流量変 動モデルでは, 各水封水位 $\mathbf{H}_{n}$ の組合せによりいくつ かのモデルを構築して最も再現精度の高いモデルを選 出した. 㹂坑 A の例を図-13 a) に示す．モデルによる 再現結果は, 極めて精度良く変動を捉えることができ ていることがわかる．次に構築されたモデルにおいて， 降水量 $R_{n}$ に0，変化している水封水位 $\mathbf{H}_{n}$ に管理値 $\mathrm{Hc}_{\mathbf{n}}$ を与えてシミュレーションした結果 $\tilde{\mathbf{Q}}_{n}$ を同じ図 中の太破線で示した。降水影響除去後の給水流量変動 


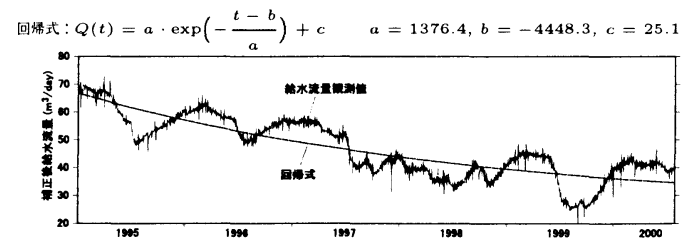

a) 回㷌結果

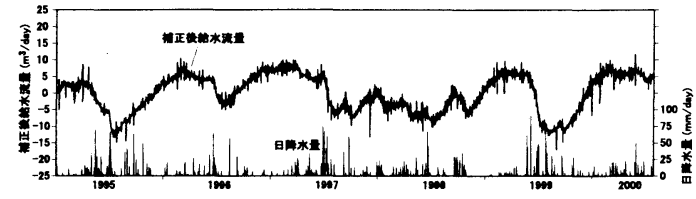

b) 補正後 朢坑 $\mathrm{A}$ 給水流量

図-11 竪坑 A 給水流量の漸減現象の指数関数回帰補正

はベースが $5 \mathrm{t} / \mathrm{day}$ 程度増えて, 変動幅は極めて小さく 滑らかな変動である. 図-13 b) は再現値から降水影響 除去值を引いた給水流量変動に占める降水影響成分を 示しており，降水量の多い期間では約 $15 \sim 17 \mathrm{t} /$ day 程 度の減少に寄与していることがわかる.

同様に湧水流量変動モデル（式 (18)）についても, 補 正後全体湧水流量を用いて水封水位 $\mathbf{H}_{n}$ および給水流 量 $\mathbf{Q}_{n}$ の組合せによりいくつかのモデルを構築して最 も再現精度の高いモデルを選出した．その結果を図-14 a)に示した. モデルによる再現結果は, やはり変動傾 向を精度良く捉えられていることがわかる. 次に構筑さ れたモデルにおいて降水量 $R_{n} に 0$ ，水封水位 $\mathbf{H}_{n}$ に管 理値 $\mathbf{H} \mathbf{c}_{n}$, また給水流量 $\mathbf{Q}_{n}$ には先に構築したモデル 式 (17) による降水影響除去值 $\tilde{\mathbf{Q}}_{n}$ を与えてシミュレー ションした結果を, 同図中の太破線で示した。また再 現値との差（降水影響成分）を図-14b) に示した。降 水影響除去後の湧水流量はほとんど変動せず，湧水流 量変動に占める降水影響成分は最大で約 $20 \mathrm{t} / \mathrm{day}$ と全 体量（220～250t/day）に対して 5 10\%程度であるこ とがわかった.

\section{（3）孔内地下水位変動のモデル化と降水影響評価}

ここでは各孔内地下水位毎に式 (15) のモデルを構築 して，それぞれの降水による影響を評価する．水封水 位 $\mathbf{H}_{n}$, 給水流量 $\mathbf{Q}_{n}$ および湧水流量 $\mathbf{F}_{n}$ の組合せによ りいくつかのモデルを構築して, 最も再現精度の高い モデルを選出した。

最適モデルにより得られた再現結果として，W-4 孔 およびW-11孔の例をそれぞれ図-15 および图-16に示 した. 各図 a)の細破線が観測値, 太実線が再現值を示 している. どちらもかなり精度良く地下水位変動の傾 向を捉えることができている.

構築されたモデルにおいて, 降水量 $R_{n} に 0$, 水封水

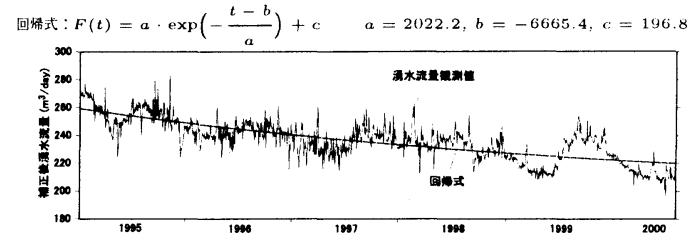

a) 回㷌結果

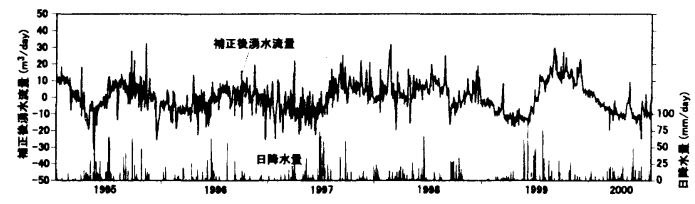

b) 補正後 全体湧水流量

図-12 全体湧水流量の漸減現象の指数関数回帰補正

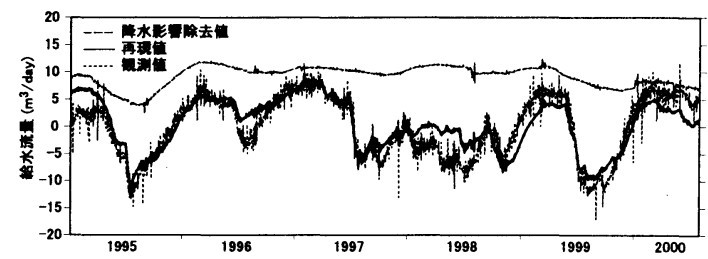

a) MAR モデルあてはめおよび降水影響除去結果

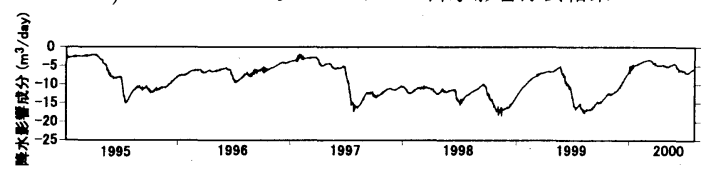

b) 降水影響成分

図-13 竪坑 $\mathrm{A}$ 給水流量に占める降水影響成分の抽出

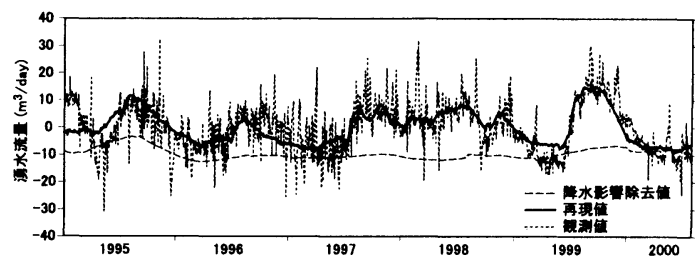

a) MAR モデルあてはめおよび降水影響除去結果

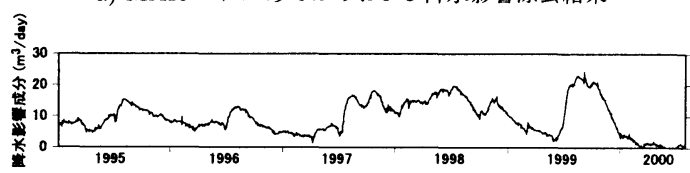

b) 降水影警成分

図-14 全体湧水流量に占める降水影響成分の抽出

位 $\mathbf{H}_{n}$ に管理値 $\mathbf{H} \mathbf{c}_{n}$, 給水流量 $\mathbf{Q}_{n}$ および湧水流量 $\mathbf{F}_{n}$ には先に求めておいた降水影響除去值 $\tilde{\mathbf{Q}}_{n}$ および $\tilde{\mathbf{F}}_{n}$ を 与えて降水影響除去後の孔内水位変動をシミュレーショ ンした結果を同図中の太破線で示した。また再現值と の差（降水影響成分）を各図 b) に示した.

W-4 孔の降水影響除去後の地下水位は, ほとんど変 


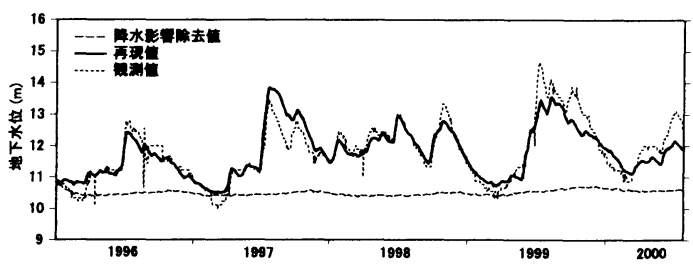

a) 降水影響除去シミュレーション

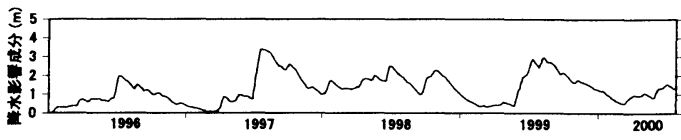

b) 降水影響成分

図-15 MAR モデルによる降水影響除去結果（観測孔 W-4）

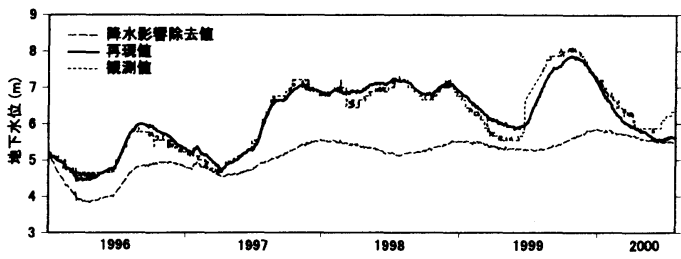

a) 降水影響除去シミュレーション

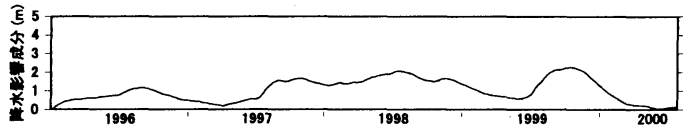

b) 降水影響成分

図-16 MAR モデルによる降水影響除去結果（観測孔 W-11）

動せず実測最低水位（約 $10.5 \mathrm{~m}$ ）付近でほほ一定とい う結果となった。実測水位に占める降水影響成分は最 大 $3 \mathrm{~m}$ 以上に及んでいる．W-11 孔の降水影響除去後の 地下水位は, 最初の数ヶ月間は $1 \mathrm{~m}$ 程度下降した後上昇 するという挙動を示しているが，それ以降の変動は僅 かであり，降水影響成分が $1 \sim 2 \mathrm{~m}$ 程度含まれていると 評価された.W-4 孔と比べると降水影響成分はかなり 滑らかで，より大きな時間遅れを伴っていることが推 察される。

なお初期の数ヶ月間シミュレーション值が安定してい ないのは, MAR モデルの式 (15) にあてはめる際に次 数 $M$ 個分の初期値の影響が考えられる。つまり降水影 響を含んだ孔内水位実測値を初期値として入力してい るために，この影響が自己回帰成分によって数ヶ月間継 続していることによるものと考えられる。このように シミュレーション初期は不安定となることがあるため, 降水影響評価として信頼できるのは，シミュレーショ ン初期の半年間を除いた以降と考えるのが妥当である. ただしW-4 孔でも同様の問題は考えられるが，孔内地 下水位の初期値に占める降水影響分の割合が小さかっ たために不安定な期間は短いものと考えられる.

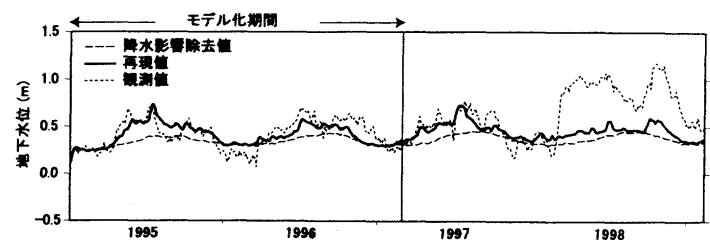

a) 降水影響除去シミュレーション

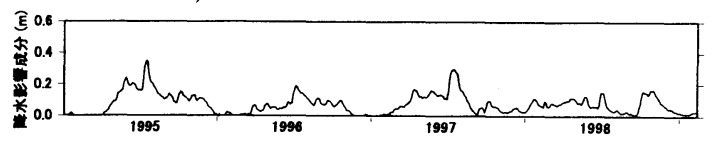

b) 降水影響成分

図-17 MAR モデルによる降水影響除去結果（観測孔 W-9）

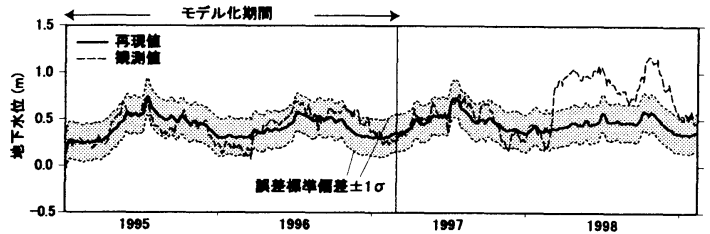

a) MAR モデルによるモデル化

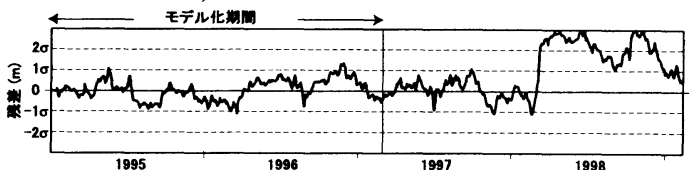

b) 真の地下水位との残差とモデル推定誤差

図-18 MAR モデルによる地下水位管理の概念（観測孔 W-9 の例)

W-9 孔については，前章で実施した状態空間モデル により気圧，潮汐，降水影響成分を分離した後の補正 後地下水位（図-8）に対して, 式 (15) のモデルによる 検討を実施した。しかしながら対象期間全体について モデルの適用を行ったところ，どの変数の組合せにつ いても十分な再現精度が得られなかった．前述したよ うに補正後地下水位変動では 1998 年 3 月頃に約 $50 \mathrm{~cm}$ の上昇が認められ，特にこの付近の影響により全体の 再現精度が悪くなっていることがわかった。 そこで最 初の約 2 年間（1995 年 1 月 1 日 1997 年 3 月 1 日）て 最適モデルの構築を行ったところ, 精度良く変動を捉 える事ができた。図-17 a) は構築されたモデルにより 対象期間全体を再現したものであり，細破線が観測値， 太実線が再現値を示している。これを見ると 1998 年 3 月頃の水位上昇以外の変動は精度良く捉えられている.

また同様に構築されたモデルにおいて，降水影響除 去後の孔内水位変動シミュレーション結果を同図中の 太破線で，また再現値との差（降水影響成分）を図-17 b) に示した。これから水位变動に占める降水影響成分 は最大 $0.3 \mathrm{~m}$ 程度であることがわかった。 


\section{（4）孔内地下水位の計測管理}

ここではW-9 孔を例に，提案するモデルによる計測 管理モデルとしての可能性について述べる. 図-18 a) は, 前節で最初の約 2 年間をモデル化期間として構築 した最適モデルによる再現值にモデルの誤差標準偏差 （式 (15) の最後の誤差項 $\mathbf{e}(t)$ の標準偏差）の $\pm 1 \sigma$ の範 囲を同時に示したものである.図中の破線が観測值（た だし状態空間モデルによる気圧，潮汐，降水影響成分 を除いた後の補正後水位）を示し，実線がモデルによ る再現値であり，グレーハッチの範囲が $\pm 1 \sigma$ の範囲で ある.また図-18 b) は観測値と再現值の残差を $\pm 1 \sigma$, $\pm 2 \sigma$ の範囲と共に示している.

これらを見るとわかるように, 約 2 年間のモデル化 期間とその後約 1 年間（1998 年 2 月頃迄）は変動傾向 は捉えられており，残差もモデル標準偏差のほほ範囲 内に収まっているが，1998 年 3 月頃に扔ける約 $50 \mathrm{~cm}$ の水位上昇を全く捉えることができず，以降は，誤差 が $+2 \sigma$ 以上となっている。 このことから，この時期を 境に水理構造に何らかの変化が生じて水位が上昇した ものと考えられる.

このように本モデルを用いることで，モデルに含ま れない影響による僅かな地下水位変化を十分な精度で 検出できることがわかった.すなおち本モデルにより 計測管理を行うことで, 運用中の日々の地下水位変動 の中から, 水理構造の変化等に伴う水位変動（異常）の 検出が可能であることを示唆するものである.

\section{（5） 孔内地下水位の変動要因評価}

MAR モデルにおいて，特定の変数の変動に対する 他の変数の寄与の程度を相対的に表した量が相対ノィ ス寄与率 (文献9) 参照) であり, 対象変数変動の周期成 分毎に算出される. 上記のW-4 孔拉よびW-11 孔地下水 位の最適 MAR モデルにおいて, 孔内地下水位の変動 に対する他の変数の相対ノイズ寄与率を表したグラフ が図-19 である．グラフの横軸は孔内地下水位変動の 周期成分（単位は日）を示し，縦軸は各変数毎のノイ ズ寄与率を累積して示している. 自身 (孔内地下水位) を含む全ての変数の寄与率を累積すると 1 となる.

W-4 孔およびW-11 孔のノイズ寄与率ともに，長周期 成分（月周期 一年周期）ほど他の变数の寄与率が大き く, 短周期成分（1 数日周期）は自己成分が大きい. いずれの地下水位変動も長周期成分が卓越していると 考えられるため, その変動は他の変数による影響を強 く受けていることがわかる．個別に見るとW-4 孔では， 多くの周期成分で日降水量が $40 \%$ 程度奇与しているこ とがわかる。これに対してW-11孔では，200日以上の 長周期成分において竪坑 C の給水流量が $60 \%$ 程度の寄 与率を示している。

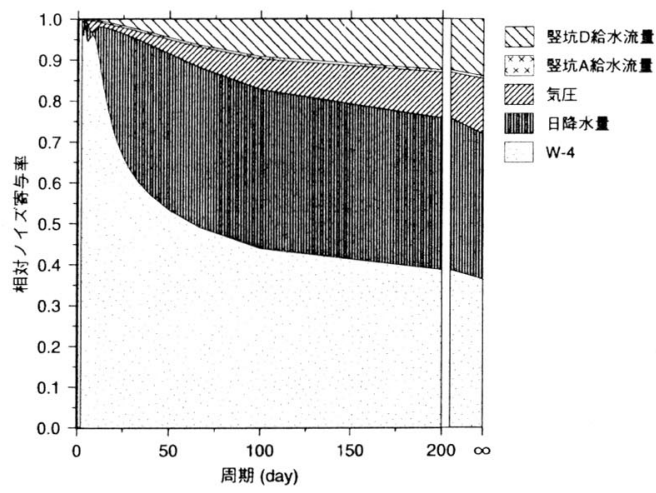

a) W-4 孔

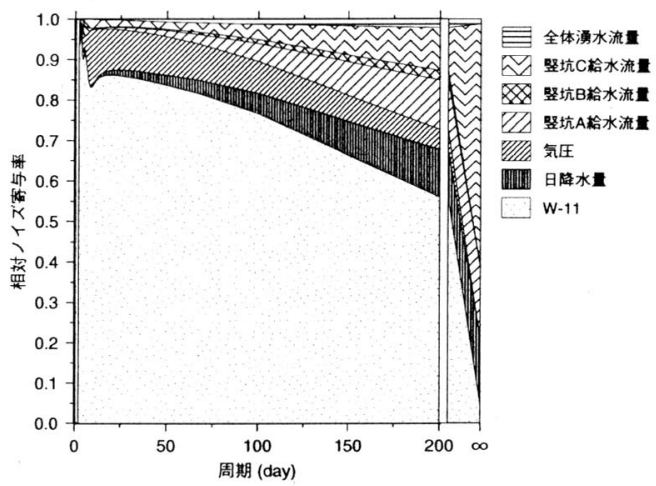

b) W-11 孔

図-19 相対ノイズ寄与率

14 孔全ての観測孔について構築したMAR モデルに おいて，ノイズ奇与率による評価を実施して，定性的に 要因分析を行った結果を図-20に示す。まず図-20 a) は日降水量の寄与が高い孔の範囲を示しており，これ を見ると基地周縁部に位置していることがわかる。こ れは夕ンク敷地内は給水された水封水の影響で地下水 位が制御されているために，直接的な降水の影響を受 けにくいことによるものと考えられる．㹂坑 C 給水流 量の寄与率が高い孔は図-20 c) に示す範囲で, 南西側 の観測孔地下水位に寄与している。ただし給水流量の 絶対量が最大で $15 \mathrm{~m}^{3} /$ day 程度と少ないことからすれ ば, 給水流量が直接に影響を与えているのではなく, 一 定に制御されている水封水位の本来の变動が,この範 囲の孔内水位変動と関連が深いことを意味するもので ある. 図-20 b) およびd) はそれぞれ㹂坑 B および堅 坑 D 給水流量の寄与する観測孔を示している. 何れも 水封水の注入範囲にある程度一致した位置の観測孔地 下水位に関連があることがわかる，ただし水封トンネ ルの位置関係からだけでは関連性の説明が付かない観 測孔も存在しており、これらは東西方向を主体とする 亀裂帯の賦存状態による地質構造の影響が考えられる. 


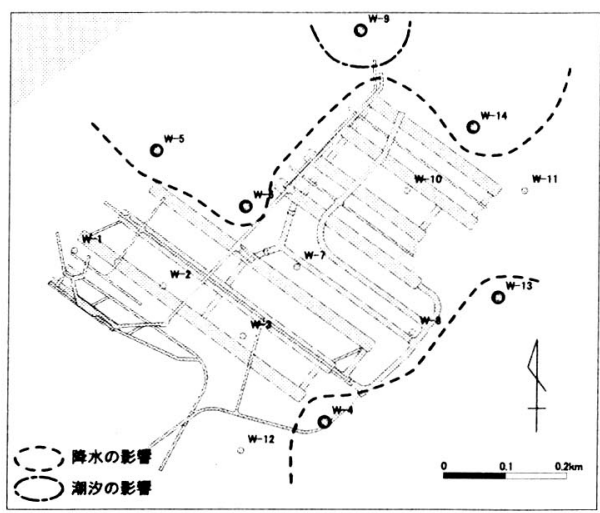

a) 日降水量・潮汐が寄与する孔内地下水位

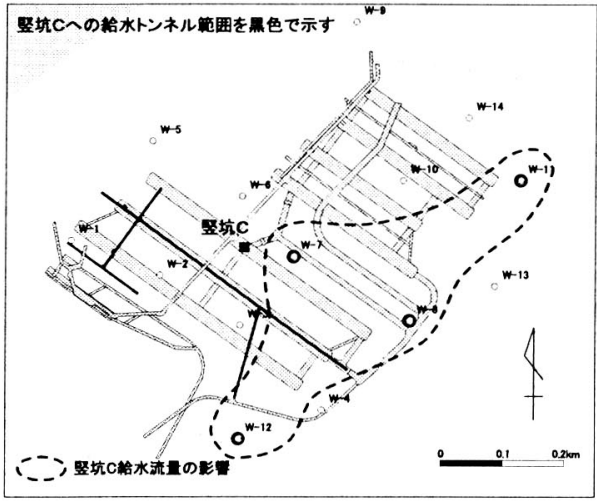

c) 竪坑 C 給水流量が寄与する孔内地下水位

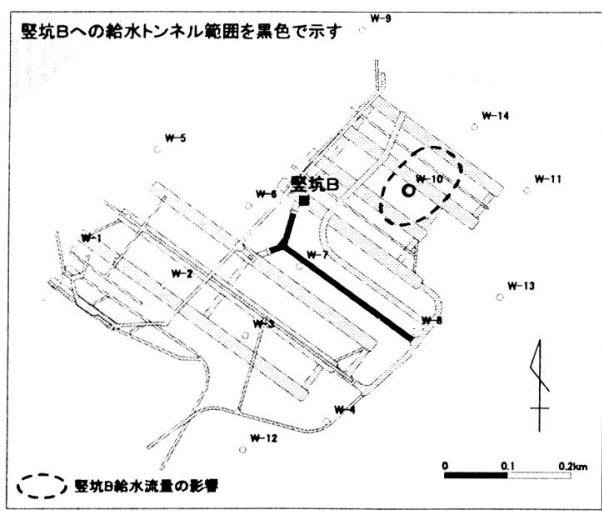

b) 竪坑 B 粭水流量が奇与する孔内地下水位

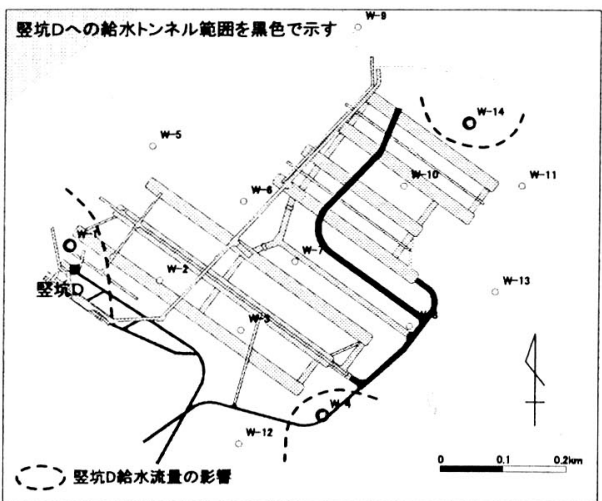

d) 竪坑 D 給水流量が寄与する孔内地下水位

図-20 変動要因の評価

\section{5. まとめ}

本論文では, 菊間基地における 1 日毎の地下水関連 デー夕を用いて, 統計的な時系列解析手法による孔内 地下水位変動のモデル化と気圧や潮汐, 降水による影 響の分離・評価を実施した。結果をまとめると以下の 通りである。

- 状態空間モデルによる気圧・潮汐・降水影響成分 の分離手法では, 潮汐の影響を強く受けて変動す るW-9 孔地下水位については精度良く分離可能で あり, 潮汐による変動成分が約 $80 \mathrm{~cm}$ 程度存在する.

- 地下水位変動における降水の影響は, 給水流量や 水封水位などの制御に伴う影響を複雑に受けてい るため，単純な線形モデルでは表しきれない.

・給水流量や水封水位など水封制御データによる相 互の影響を考慮した制御系多変量自己回帰 (MAR) モデルによる検討では，漸減現象を補正した給水 流量，湧水流量データをモデルに組み込むことで， ほとんどの孔内地下水位变動が十分な精度で再現 できる。
- 構築されたモデルにおいて, 降水を 0 とした時の シミュレーションにより, 各観測孔地下水位変動 に占める降水影響成分の評価が可能である。

- 構築されたモデルの再現値と観測値の残差を管理 することで，気象や潮汐等の自然因子による影響 を除いた，水理構造の変化等による水位変化（異 常）を十分な精度で検出可能である.

・ノイズ寄与率を基に変動要因の分析をすることで, 各観測孔地下水位の変動傾向の分類が可能であり, 水封機能の管理上役に立つものと考えらる.

以上，水封式岩盤タンク周辺の地下水挙動は，水封制 御による影響により複雑な因果関係が成り立っており， これらの関係を提案する時系列解析モデルにより十分 な精度でモデル化でき，水封機能管理モデルとしての 適用性が示された。 今後は串木野基地や久慈基地にお けるデータにおいても検討を行い，適用性を示してい く所存である。 


\section{参考文献}

1) 浅岡弘暢, 宇野尚雄: 大規模工事前後の地下水位変動の 分析, 土木学会第 49 回年次学術講演会梗概集, III- 98 , pp.190-191， 1994.

2) Kitagawa,G. and Matsumoto,N. : Detection of coseismic changes of underground water level., Jour.of American Statistical Association, pp.521-528, 1996.

3) 松本則夫, 高橋誠: 地震にともなう地下水位変化検出の ための時系列解析〜静岡県浜岡観測井への適用〜，地震， 2-45 巻, pp.407-415, 1993.

4) 赤池弘次, 北川源四郎編 : 統計学選書 時系列解析の奏際 II, 朝倉書店, p.218, 1995.

5) 赤池弘次, 中川東一郎：ダイナミックシステムの統計的解 析と制御, サイエンス社, p.189, 1972.
6) 例えば, 中村秀夫, 内田主幹: 統計モデルによる火力発電 プラントの解析と制御, システム・制御・情報, Vol.34, No.1, pp.9-15, 1990.

7) 本多眞, 鈴木誠, 百田博宣:地下水挙動への多变量自己回㷌 モデルの適用, 土木学会論文集, No.529/III-33, pp.93102, 1995.

8) Akaike,H. : A new look at the statistical model identification. IEEE Trans. on Automatic Control, Vol. AC19, No.6, pp.716-723, 1974.

9) 尾崎統, 北川源四郎編：統計学選書 時系列解析の方法, 朝 倉書店, p.185, 1998.

(2002.7.15 受付)

\section{STATISTICAL ANALYSIS OF GROUNDWATER BEHAVIOR AROUND WATER SEALED ROCK CAVERN TAKING METEOROLOGICAL AND TIDAL DATA INTO ACCOUNT}

Kazuo UEDE, Akio OKAMOTO, Makoto HONDA, Makoto HASEGAWA and Makoto SUZUKI

Groundwater levels around the water sealed rock cavern are greatly fluctuating by the influence of not only precipitation, air pressure and earth tide, but also changes of water supply for water curtain control. It is very important for maintenance and control of water curtain functions to detect a minor fluctuation caused by changing hydrological structure with earthquake or others in the greatly fluctuated observed values. In this paper, it is shown that the effect of meteorological phenomena can be clearly separated by statistical time series analysis and that the changes of hydrological structure can be detected. It's also shown that the proposed methods are available for the maintenance system. 